\title{
УМОВИ АЛЬТЕРНАЦІЙ У СЛОВОТВІРНИХ ПАРАДИГМАХ ДЕВЕРБАТИВІВ В УКРАЇНСЬКІЙ, РОСІЙСЬКІЙ І ПОЛЬСЬКІЙ МОВАХ
}

\begin{abstract}
Демешко I. М. Умови альтернацій у словотвірних парадигмах девербативів в українській, російській і польській мовах.

У статті окреслено перспективу дослідження віддієслівних дериватів в українській мові в контексті теоретичних здобутків сучасної лінгвістики, умови альтернацій у словотвірних парадигмах девербативів в українській, російській і польській мовах.

Ключові слова: словотвірна морфонологія, девербативи, морфонема, морфонологічні процеси,
\end{abstract} вокалічні й консонантні альтернації.

Демешко И. Н. Условия альтернаций в словообразовательных парадигмах девербативов в украинском, русском и польском языках.

В статье очерчена перспектива исследования отглагольных дериватов в украинском языке в контексте теоретических достижений современной лингвистики, условия альтернаций в словообразовательных парадигмах девербативов в украинском, русском и польском языках.

Ключевые слова: словообразовательная морфонология, девербативы, морфонема, морфонологические процессы, вокаличные и консонантные альтернации.

Demeshko I. M. The conditions of alternations in derivatives paradigmas in Ukrainian, Russian and Polish languages.

The article outlines the perspective of the research of verbal derivatives in Ukrainian in the context of theoretical achievements of modern linguistics, the conditions of alternations in derivatives paradigmas in Ukrainian, Russian and Polish languages.

Key words: word-building morphonology, deverbatives, morphonema, morphonological processes, vowel and consonant alternations.

Розширення морфонологічної проблематики стає наслідком того, що повнота й адекватність морфонологічного опису знаходиться в залежності від результатів аналізу фонологічного і граматичного ладу мови, а морфонологічний опис набуває аналітичного характеру, тому дослідження й опис формальних ознак мовних одиниць з погляду системно-структурної лінгвістики залишається актуальним. Труднощі морфонологічного опису пояснюються і тим, що в наукових розвідках зі слов'янської морфонології спостерігаються різні морфонологічні концепції, наявність різних програм аналізу матеріалу, неоднорідність накопиченого матеріалу, а це ускладнює теоретичне узагальнення отриманих результатів.

Метою наукової розвідки $\epsilon$ дослідження синхронного опису морфонологічних трансформацій девербативів субстантивної та ад'єктивної зон. Досягнення поставленої мети передбачає розв'язання таких завдань: 1) установити механізми впливу на зовнішній вигляд девербативів; 2) описати морфонологічно релевантні ознаки кореневих (осно́вних) та афіксальних морфем для девербативів в українській, російській і польській мовах; 3) з'ясувати характер дії форманта на твірну основу; 4) виявити умови альтернацій у словотвірних парадигмах девербативів у субстантивних та ад'єктивних зонах в українській, російській і польській мовах. 
Для української мови, як і для всіх слов'янських мов, характерні морфонологічні модифікації, що функціонують у формо- і словотвірній системах. На шляху становлення морфонології як науки вагомий крок був здійснений представниками Казанської лінгвістичної школи I. О. Бодуеном де Куртене та його послідовником М. В. Крушевським. I. О. Бодуен де Куртене ввів у науковий обіг термін «альтернація», провів класифікацію чергувань, а також звернув увагу на морфологічну значущість окремих типів чергувань: «Гомогенні фонеми (що виникли 3 однієї фонеми) в морфології відіграють таку ж роль, як і рухомі словотворчі морфеми (афікси). Подібно до суфіксів, префіксів, корелятиви теж слугують засобом розрізнення морфологічних категорій» [1, с. 301].

В українських граматиках (О. О. Потебні, П. Г. Житецького, К. П. Михальчука, А. Ю. Кримського, О.О.Шахматова, С. К. Тимченка, С. Смаль-Стоцького і Ф. Гартнера) висвітлювалися питання історії української мови і лише принагідно розглядалися окремі типи чергувань.

У порівняльно-історичному мовознавстві проблеми морфонології вивчалися досить ретельно. А. Мейє в четвертому розділі «Принципи морфології» відомої праці «Вступ до порівняльного вивчення індоєвропейських мов» розглядає чергування приголосних, форми індоєвропейських морфологічних елементів (коренів, суфіксів, закінчень), різні класи слів [7, с. 166-210]. Як самостійний розділ морфонологія була представлена в граматиках слов'янських мов: російської [Грамматика 1970; Русская грамматика 1980], польської [Gramatyka współczesnego języka polskiego. Morfologia / Pod red. R. Grzegorczykowej, R. Laskowskiego, H. Wróbla 1984], чеської [Mluvnice čestiny. Fonetika. Fonologie. Morfonologie a morfemika. Tvořené slov 1986.].

Різне уявлення про структуру морфонології пояснює те, що в граматиках української, російської, польської мов морфонологію розглядають як частину формальної морфології, а в граматиці чеської мови - як функціональну фонологію морфем. Така невідповідність розділів пояснюється різним уявленням про межі, завдання i структуру морфонології. Суперечлива природа морфонологічних явищ породжує різні погляди на їхню роль у слов'янських мовах. Також ця проблема ускладнюється впливом на морфонологічні концепції різних фонологічних шкіл. Так, В. Г. Чурганова аналізує закономірності іменного і дієслівного основотворення, використовуючи теорію «сильних» і «слабких» фонем Р. І. Аванесова. Н. Є. Ільїна описує морфонологію словозміни дієслова в сучасній російській мові, В. Б. Касевич досліджує питання російської морфонології і здійснює порівняльний аналіз основних європейських i ряду східних мов, орієнтуючись на концепцію Санкт-Петербурзької (Ленінградської) фонологічної школи; В.В.Лопатін, Т. В. Попова досліджують морфонологічні типи субстантивних парадигм у сучасній російській мові, С. М. Толстая описує особливості польської морфонології 
крізь призму граматики і вияв на ії основі аналізу морфонологічних позицій i морфонологічних моделей, орієнтуючись на концепцію Московської фонологічної школи. М. В. Кравченко аналізує словотвірну морфонологію української мови і досліджує особливості словотвірних моделей, Л. О. Кондакова описує морфонологічні процеси в системі українського іменника, I. В. Козленко досліджує морфонологію словозміни дієслова в сучасній українській мові, М. Ю. Федурко описує морфонологію відіменникового словотворення в сучасній українській мові, Г.В.Пристай досліджує особливості вияву морфонологічних закономірностей у відприкметникових словотвірних гніздах із використанням морфонологічних моделей, орієнтуючись на фонологічні погляди Л. В. Щерби та Н. І. Тоцької.

У працях із морфонології української, російської, польської мов та інших слов'янських мов, орієнтованих на концепцію Московської фонологічної школи, проводиться розмежування зумовлених i незумовлених (морфонологічних) чергувань. Г. О. Винокур зазначає, що під морфонологічним чергуванням розуміється більше або менше регулярна в певній позиції зміна голосних або приголосних фонем [2, с. 428]. Слушною видається думка В. О. Горпинича, що «морфонологічним є те чергування, яке призводить до зміни звукової будови морфів і яке здатне виконувати морфотактичну функцію» [3, с. 198]. Тому аналізуючи формальні модифікації морфем, необхідно розрізняти альтернації, що мають як парадигматичний (варіанти морфем), так і синтагматичний (сполучуваність морфем) аспект, а усічення належить до морфонології слова, що виступає засобом організації морфемної послідовності (синтагматичний аспект) в межах основи мотивованого слова.

Історично склалося, що український дієслівний корінь - відкрита структура, тому при творенні похідних іменників у всіх випадках відбувається усічення дієслівної фіналі, також на межі морфем можуть відбуватися й інші морфонологічні явища: консонантні альтернації, (вокалічні - у кореневій морфемі), модифікація наголосу. Фактичний матеріал підтверджує наявність механізмів впливу на зовнішній вигляд девербативів в українській, російській і польській мовах: 1) консонантні і вокалічні альтернації; 2) операція усічення дієслівної фіналі; 3) нарощення суфіксальної морфеми; 4) модифікація наголосу. Трансформації зазнають переважно кінцеві консонанти кореневих морфем. С. М. Толстая, досліджуючи морфонологію словозміни і словотворення польської мови, зазначає, що «основа виступає об'єктом дії ряду морфонологічних перетворень, яким не піддається морфема: саме з трансформацією основи слова (твірного) в основу-морфему (похідного слова) та оформленням нової основи слова (мотивованого) пов'язані такі явища, як лінійні модифікації (усічення, нарощення) та акцентні чергування» [9, с. 61].

В. В. Лопатін наголошує, що «морфонологічний опис віддієслівного словотвору переслідує подвійну мету: 1) вияв повного інвентаря твірних 
основ, встановлення типології лінійних перетворень дієслівної основи, вияв інвентаря чергувань; 2) вияв інвентаря повокальних і поконсонантних афіксальних морфів віддієслівних слів (на першому етапі) і морфів, що викликають ті чи ті типи чергувань в основі (на другому)» [6, с. 121-122]. Як наслідок, перший тип класифікацій стосується типології твірних основ, а другий - дериваційних афіксів. Поділяємо думку, що завдання морфонологічного опису полягає в тому, щоб виявити регулярність чергувань і представити їх у вигляді певної системи i певного набору морфонологічних правил, які відносилися б до класів морфем, класів морфонологічних позицій [9, с. 80]. Установлено, що в українській, російській і польській мовах морфонологічно релевантними є фонологічні характеристики фінілі твірної основи.

Передумовою морфонологічних трансформацій повинно бути уявлення про варіації фонемного складу морфеми. С. М. Толстая зазначає, що практично неможливо оперувати повними рядами альтернантів, що маніфестують варіантність кожної морфеми, тому, як правило, морфонолог має справу з мінімально повторюваними в окремих рядах ланками, частіше всього парами фонем, які і називаються чергуваннями [9, с. 72].

Істотною ознакою українського i російського віддієслівного словотворення є взаємодія морфонологічних операцій, наприклад, усічення i консонантні альтернації: підчистити - підчищення $\{\mathrm{cT} / / ш ч\}$, наситити - насичення $\{\mathrm{T} \sim ч\}$; усічення, консонантні альтернації $\mathrm{i}$ модифікація наголосу (переміщення 3 тематичного голосного на дериваційний суфікс): городи́ти - городі́ння $\{$ д д'\}, хвали́ти - хвалі́ння $\left\{\right.$ л $\left.\pi^{\prime}\right\}$, говори́ти - говорі́ння $\left\{\mathrm{p} \sim \mathrm{p}^{\prime}\right\}$. Так, при творенні нульсуфіксальних девербативів відбуваються такі морфонологічні операції: усічення (утинання), зворотні чергування, модифікація наголосу: обложити облога $\{ж \sim \Gamma\} ;$ розлучи́ти - розлука $\{ч \sim \kappa\} ;$ усічення мотиватора, палаталізація i модифікація наголосу: зав'яза́muсb - за́в'язь $\left\{3 \sim 3^{\prime}\right\}$, заповіда́mu - зánoвidв $\{$ Д Д'\}.

Існують певні методологіі щодо опису i типології консонантних альтернацій у різних слов'янських мовах. Так, аналіз консонантних морфонологічних альтернацій приголосних при словотворенні в українській мові уможливлює висновок, що консонантні морфонологічні альтернації необхідно описувати для кожного морфонологічного класу приголосних (губних, язикових, фарингальних). Як бачимо, це дає змогу сформулювати морфонологічні правила до цілого морфонологічного класу, а не до індивідуальних одиниць - морфонем. Такий методологічний підхід може визначити регулярність і передбачувати вплив форманта на мотиватора, також передбачувати поведінку приголосних унаслідок сполучуваності з ініціаллю форманта.

Для віддієслівних іменників, утворених способом нульової суфіксації, продуктивними є вокалічні зміни в кореневій морфемі: $\{$ и i $\}$ : 
забирати - забір, збирати - збори, ви́брати - ви́бори, опиратися - опір); $\{$ о $\}:$ помолоти - поме́л; $\{\# \sim \mathrm{e}\}:$ замислити - замисел, рівняти - рівень; $\{\# \sim$ o $\}$ : запнути - запона, підіймати - підйом; $\{$ i \# $\}:$ зібрати - збір; $\{\# \sim \mathrm{i}\}$ : руйнувати - руӥна; \{о i $\}$ : заслонити - заслін, зводити - звід, настроїти настрій, обходити - обхід; \{e i $\}$ : злетітися - зліт, налетіти - наліт, потекти - потік, простертися - простір; \{0 i $\}$ : заходити - захід, зводити - звід, переводити - переві́, переходити - перехід, реготати регіт, супроводити - супровід, уклонитися - уклін, ходити - хід; у польській мові при творенні нульсуфіксальних девербативів відбуваються такі вокалічні альтернації в кореневій морфемі: $\{\mathrm{e} \sim \mathrm{a}\}:-j e z ́ d z i c ́-$-jezd, -jezda; -mierzyć - -miar; $\{\mathrm{e} \sim \mathrm{o}\}$ : -bierać - -biór; $\{\mathrm{i} \sim$ И (о)\} (у йотованих коренях): -bić (-bij) - -bój; -pić (-pij) - -pój; -rić (-rij)--rój.

У російській мові при творенні девербативів із формантами -ець, -ок можливі такі консонантні альтернації: $\{\Gamma \sim ж\}$ : лгать - люсец, двигаться двиюкок; is формантом -атор: $\{Ц \sim \kappa\}:$ мультиплициировать мультипликатор; із нульовим суфіксом (-Ø-), формантами -ун, -арь, -к-,

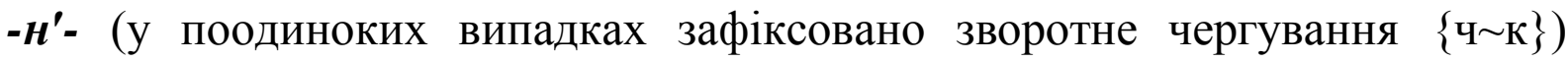
$\{\mathrm{\Psi} \sim \mathrm{K}\}:$ стучать - стук $\{\mathrm{\textrm { \tau }}\}$, трещцать - треск $\{ш ч \sim \mathrm{c \kappa}\}, \kappa р и ч а т ь-$ крикун, лечить - лекарь, точить - токарь, \{шч ск\}: пищзать - пискун, $\{\kappa \sim ч\}:$ смыкать - смычка (I. Действие. II. Веревка, цепочка) [8, с. 682], $\{\mathrm{X} \sim \amalg\}:$ naxamb - пашня.

Палаталізуючу дію на мотиватора $\left(\mathrm{C} / / \mathrm{C}^{\prime}\right)$ можуть мати такі суфікси: -ін'н'- (172): лагодити - лагодіння, дзвонити - дзвоніння, творити творіння; -ій (148): водити - водій, возити - возій, носити - носій; -іюс (9): платити - платіжс, падати - падіжс, -іль (8): крутити - крутіль. У російській мові палаталізуючу дію на мотиватора має формант -ин-: pacnaдаться - pacnaduнa $\{$ д д'\}, у польській мові - форманти -idt-, -in-iw-: kropidło, wyglądzina, nosiwo. При творенні девербативів субстантивної зони на -ін'н'-, -iй, -iль, -iжc, крім палаталізації, може

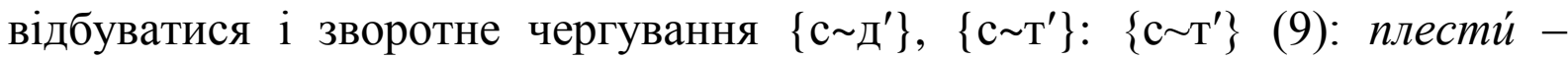
плеті́ння, извісти́ - цвіті́ння, масти́ти - масті́ння; \{с $\left.\sim д^{\prime}\right\}$ (8): вести́ веді́ння, пря'сти - пряді́ння; замести́ - заметі́ль.

У російській мові депалаталізуючу дію на мотиватора $\left(\mathrm{C}^{\prime} / / \mathrm{C}\right)$ мають

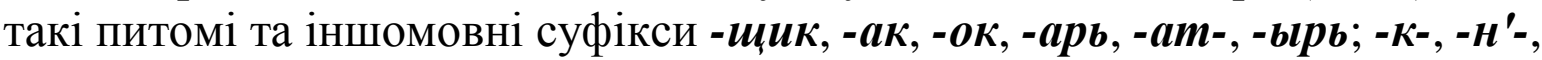
-aнm, -ор, - amop в іменниках чоловічого і жіночого роду: $\left\{\mathrm{p}^{\prime} \sim \mathrm{p}\right\}:$ сверить -

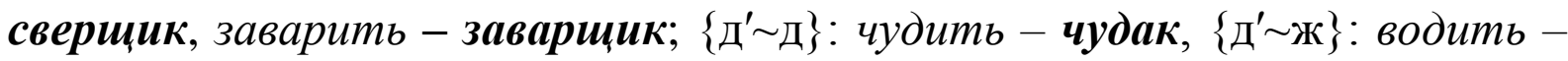
вожкк, \{Д' Д\}: поводить - поводырь, загородить - загородка, сходить сходня; $\left\{\mathrm{p}^{\prime} \sim \mathrm{p}\right\}:$ сверить - сверка, эмигрировать - эмигрант, концентрировать - концентрат, реставрировать - реставратор, консультировать - консультант, конвертировать - конвертор, агити́ровать - агита́mор, инвестировать - инвестор, агитировать агитатор; $\left\{\mathrm{H}^{\prime} \sim \mathrm{H}\right\}:$ манить - манок, звонить - звонарь, экспонировать экспонат, чеканить -чеканка; $\left\{\mathrm{T}^{\prime} \sim \mathrm{T}\right\}:$ катить - каток; $\left\{\Omega^{\prime} \sim \pi\right\}:$ напилить - 
напилок; $\left\{\mathrm{c}^{\prime} \sim \mathrm{c}\right\}:$ инверсировать - инверсор. У польській мові депалаталізуючу дію має нульовий суфікс: $\left\{\mathrm{m}^{\prime} \sim \mathrm{m}\right\}$ : -dzielić - -dziat (na-, prze-, roz-); \{p' p \}: -czepić - -czep (za-, przy-, w-); -czepa (przy-, na-); \{b' $\sim \mathrm{b}\}$ : -robić - -rob (nie-, prze-, wy-); \{ćct $\}$ : - świecić - -świat (nad-, po-); -plata (o-,

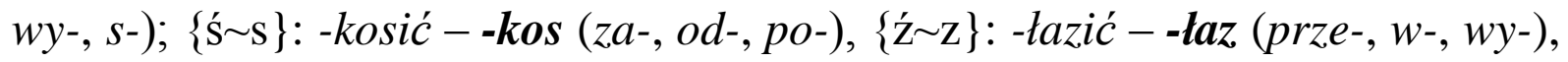
-wozić- -woz (po-, do-, w-, wy-).

У словотвірній морфонології віддієслівних похідних сильніше виражені консонантні зміни, оскільки морфемне варіювання, зумовлене впливом кінцевої приголосної фонеми у морфемі. Наголошуючи на тому, що морфонологічні явища не індивідуальні, а системні, регулярні, прогнозовані, можна переконатися на прикладі консонантних альтернацій. Характерно, що саме відповідна морфонологічна будова визначає готовність морфеми до тієї чи тієї зміни. Так, консонантні альтернації C//C, $\mathrm{P} / / \mathrm{Pl}, \mathrm{K} / / \check{C}$ характерні для девербативів субстантивної та ад'єктивної зон на -ен'н'-, -ен- в українській мові (розкла́сти - розкладення, розкладений \{с д $\}$, відобразити - відображення, відображений $\{3 \sim ж\}$, знешкодити знешкодження, знешкоджений, обсадити - обсадження, обсаджений, доводити - доводження \{Д Дж\}, просити - проше́ння, про́шений, вгостити - вгощення $\{$ ст $\sim$ Ш, розпекти -розпечення, розпечений $\{\kappa \sim 4\}$, звести - зведення, зведений $\{$ с $\sim$ \}, виробити - вироблення, вироблений,

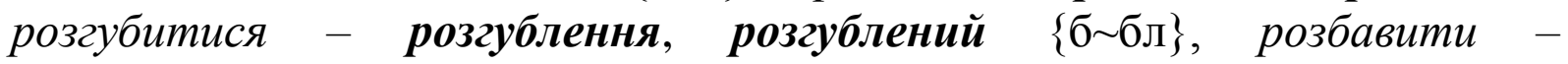
розбавлення, розбавлений $\{$ В ВЛ\}, закріпити - закріплення, закріплений, захопи́ти - захоплення, захоплений $\{\Pi \sim \Pi л\}$, графити - графлення, графлений $\{ф \sim ф л\}$. Необхідно зазначити, що в російській мові консонантні альтернації відповідного типу $\left(\mathrm{C} / / \mathrm{C}, \mathrm{C}^{\prime} / / \mathrm{C}, \mathrm{C} / / \mathrm{C}, \mathrm{C}^{\prime} / / \mathrm{C}, \mathrm{P} / / \mathrm{Pl}^{\prime}\right.$, К//С̆) також характерні для девербативів субстантивної та ад'єктивної зон на -ениј-, -енн-; -ин-, -ив-, -атай, -ай (соорудить - сооруюсение \{Д ж\},

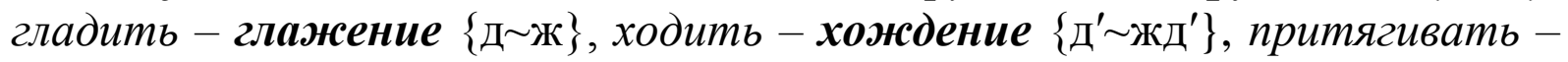
притяжение $\{\Gamma \sim ж\}$, свергнуть - свержение $\{\Gamma \sim ж\}$, сообразить соображсение $\left\{3^{\prime} \sim Ж\right\}$, носить - ношение $\left\{\mathrm{c}^{\prime} \sim \amalg\right\}$, следить - слежка $\left\{д^{\prime} \sim ж\right\}$, сопоставить - сопоставление, явить - явление, явле́нный

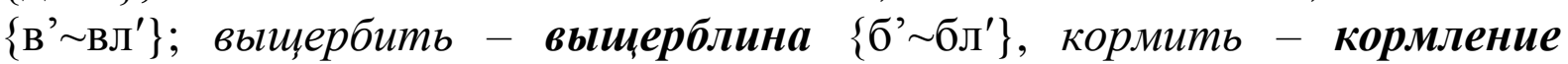
$\left\{\mathrm{M}^{\prime} \sim \mathrm{M}^{\prime}\right\}$, укрепить - укрепление $\left\{\Pi^{\prime} \sim \Pi^{\prime}\right\}$, графить - графление $\left\{\phi^{\prime} \sim \phi л^{\prime}\right\}$, попить - топливо $\left\{\Pi^{\prime} \sim \Pi^{\prime}\right\}$, пригорать - пригарина $\left\{\mathrm{p} \sim \mathrm{p}^{\prime}\right\}$, продыхать - продушина $\{\mathrm{X} \sim \amalg\}$, гласить - глашатай $\left\{\mathrm{c}^{\prime} \sim \amalg\right\}$, уродитьсяурожсай $\left\{д^{\prime} \sim ж\right\}$, сплотить - сплочение $\left\{\mathrm{T}^{\prime} \sim \mathrm{\Psi}\right\}$.

Установлено, що в словотвірній морфонології віддієслівних іменників сильніше виражені консонантні альтернації при творенні похідних на -енн- (C//C, P//P1, К//С̆), -iн'н'-, -iй, -iльь, -iюc (C//C', P//Pl), *ja (К//С̆), а при творенні віддієслівних іменників, утворених способом нульової суфіксації, консонантні альтернації $\left(\mathrm{C} / / \mathrm{C}^{\prime}, \mathrm{K} / / \mathrm{C}^{\prime}\right)$ виражені слабше: $\left\{\Omega^{\prime} \sim л\right\}:$ обстріляти - обстріл; $\left\{\mathrm{p}^{\prime} \sim \mathrm{p}\right\}:$ виміряти - вимір, докоряти - докір;

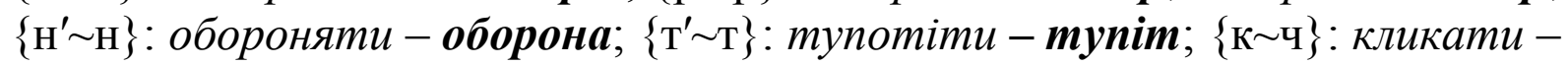


клич; \{ждж зд\}: виїжджати - виїзд, роз'їжджатися - роз'їзд; $\left\{3 \sim 3^{\prime}\right\}$ :

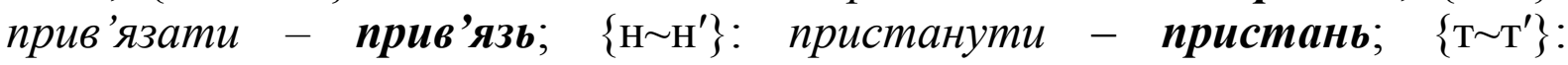
пам'ятати - пам'ять; \{ч к\}: перелічити - перелік, научити - наука; \{шч ск\}: пищуати - писк, верещуати -вереск.

При творенні нульсуфіксальних девербативів для української, російської і польської мов характерне зворотне чергування: пор.: укр.: $\{ж \sim \Gamma\}:$ поважати - повага, напружити - напруга, пружити оказіональне пруг (С. Маланюк), обложити - облога; рос.: $\{ж \sim \Gamma\}$ :

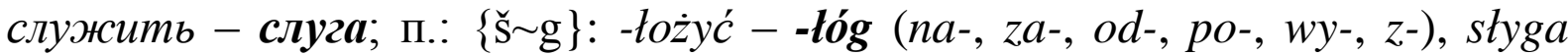
(za-, ob-, po-, $u$-). Зворотні чергування мають подвійне навантаження: поперше, вони маркують напрямок дериваційного процесу при творенні мотивата; по-друге, вказують на зміну напрямку мотивації.

У польській мові при творенні нульсуфіксальних девербативів, як і в українській, і російській мовах, відбувається усічення тематичних показників і депалаталізація приголосних: $\left\{\mathrm{r}^{\prime} \sim \mathrm{r}\right\}:-t w o r z y c ́$ - -twór $(z a-$, wy-, roz-), -warzyć - -war (na-, wy-, s-); \{1'〜1\}: -dzielić - -dzial (na-, prze-, roz-), -walić - -wat (na-, prze-, za-), -myślić - -myst (na-, prze-, za-); \{ńn $\}$ : -gonić -gon (za-, przed-, wy-), -kłonić - -kłon (u-, wy-); obrona, ochrona. Необхідно зазначити, що тільки для словотвірної морфонології нульсуфіксальних девербативів польської мови характерні такі консонантні альтернації \{3 d \}: -chodzić - -chód (za-, pod-, wy-), -jeźić - -jazd (za-, przed-, pod-, wy-, z-, roz-), -glada (za-, o-), \{č $\sim \mathrm{k}\}:-s k o c z y c ́$ - -skok (za-, od-, pod-, z-, wy-), a форманти -acja, -ač, -adt-, -ak, -al, -alnik, -anin-, -ant, -ator, -c-, -dt-, -ent, приєднуючись до дієслівних основ не викликають чергувань: normalizować, opowiadacz, zaganiacz, oracz, ruchadło, zabierak, odmotak, kopal, kowal, pralnia, kopalnia, skubalnia, pralnik, bieganina, gadanina, pisanina, debiutant, komunikant, kwalifikant, manipulant, regulator, likwidator, dawca, nalazca,hodowca, szydto, reagent, dyrygent.

Уважаємо за необхідне наголосити на тому, що дія форманта на твірну основу певною мірою залежить від його фонологічної структури. Так, якщо ініціаль суфікса складається 3 голосної переднього ряду /i/, то відбуваються консонантні альтернації $\mathrm{C} / / \mathrm{C}^{\prime}$ (палаталізація приголосного мотиватора), а якщо /e/ - консонантні альтернації P//P1, Т//С̆ (пор. ходити ходіння, возити - возіння, платити - платіюн, свердлити - свердлій; поглибити - поглиблення, розграфити - розграфлення; коптити копчення). Отже, загальною умовою реалізації морфонологічних змін $є$ якість кінцевої фонеми дієслівної основи.

Опис словотвірної морфонології віддієслівних дериватів доцільно починати зі встановлення альтернантів мінімальних морфонологічних сегментів. Визначення функціональних класів приголосних дає можливість встановити загальні морфонологічні умови, спрогнозувати та описати економним способом поведінку приголосних при поєднанні з будь-яким формантом, оскільки не кожна фонема чергується з будь-якою фонемою 
мови: в альтернаціях перебувають певні фонеми, утворюючи закриті ряди [4]. Необхідно зауважити, що кожен член альтернації виступає аналогом змінного сегмента морфа і певної морфонологічної позиції (палаталізації, депалаталізації, амбівалентної) [5].

Фонемна характеристика структурних типів дієслівних основ має певні відмінності в інвентарі фонем, а також в можливостях комбінаторики фонем. У препозиції кінцевої приголосної фіналі дієслівної основи можуть реалізуватися всі голосні і 18 приголосних фонем. Не формують фіналь

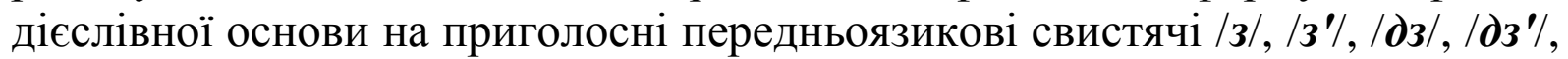
$/ \boldsymbol{u} /, / \boldsymbol{u}^{\prime} /$, шиплячі $/ \boldsymbol{u} /, / \boldsymbol{\partial} \boldsymbol{c} /, \mathbf{u} /$, передньоязикова м'яка $/ \boldsymbol{u}^{\prime} /$, задньоязикові $|\boldsymbol{t}|, \mid \boldsymbol{x} /$, глоткова $/ \boldsymbol{z} /$ і губна $/ \boldsymbol{\phi} /$. Усі класи приголосних представлені перед $\mid \boldsymbol{a} /$, перед /u/ - передньоязикові тверді і губні, перед /i/ - передньоязикові м'які, шиплячі і губні. Обмеження в побудові дієслівної основи має

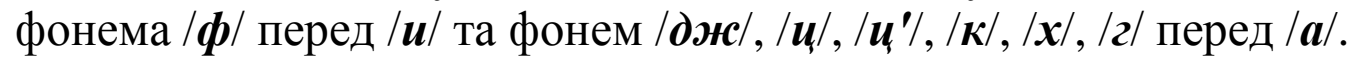

Близькість морфонологічної будови фіналі твірних основ семантично й етимологічно неоднорідних дієслів не може забезпечити однотипність та однорідність морфонологічної поведінки у структурі девербативів субстантивної та ад'єктивної зон. У слов'янських мовах морфонологічно значущою $є$ твірна основа, зокрема тематичними показниками визначається вибір тих чи тих формантів, що приєднуються до неї, складова характеристика, фонемний склад (якість кореневого голосного і кінцевого приголосного). Головними критеріями, що визначають умови альтернацій у словотвірних парадигмах девербативів в українській, російській і польській мовах є тип основи (вокалічні, консонантні основи), характер останнього приголосного основи (повної чи усіченої) та ініціаль дериваційного засобу.

$\mathrm{y}$ формальному плані найбільшою комплексною одиницею $\epsilon$ словотвірне гніздо, яке виконує домінуючу роль у систематизації українського словотвору, оскільки саме в ньому чітко простежуються закономірності дії внутрішнього механізму, який характеризується ієрархічними зв'язками між іншими комплексними одиницями словотвірної системи. Виходячи зі специфіки дієслова як базового (вершинного) слова словотвірного гнізда, стверджуємо, що найчастотнішою 3 усіх морфонологічних операцій $є$ усічення (утинання), консонантні і вокалічні альтернації (переважно в кореневій морфемі) та модифікації наголосу.

Аналіз морфонологічних особливостей девербативів дає змогу зробити такі висновки:

1. При творенні девербативів субстантивної та ад'єктивної зон відбувається модифікація твірної основи. Загальна особливість для всіх дієслівних основ - усічення дієслівної фіналі.

2. Кожна конкретна морфонологічна трансформація у фонемному вияві осно́вних та афіксальних морфем при їхній взаємодії відбувається за наявності певних умов. Характер дії форманта на похідну основу залежить від його фонологічної структури. 
3. Дослідження морфонологічної структури дієслова у слов'янських мовах дає змогу встановити функціональну морфонологічну класифікацію приголосних за типами палаталізації і депалаталізації.

Вивчення морфонологічних особливостей девербативів при операційному підході дає змогу визначити механізм вибору оточення i модифікацію мотивата під впливом форманта. Перспективу подальших розвідок словотвірної морфонології девербативів убачаємо у вивченні морфонологічних особливостей у віддієслівних словотвірних гніздах.

\section{Умовні скорочення}

\{ \} - морфонологічний запис; \# - нульова морфонема зі змінною фонологічною репрезентацією; $\mathrm{V}$ - будь-яка голосна; C - консонантний формант у структурі морфеми, - символ чергування, С морфонологічно тверда приголосна, $\mathrm{C}^{\prime}-$ морфонологічно м'яка (палатальна) приголосна, $\mathrm{P}$ - тверда лабіальна, Pl - результат консонантної альтернації (лабіальна $+\pi$ ), C//C' - консонантні альтернації передньоязикових приголосних, P - клас губних, P//Pl - перехідне пом’якшення губних приголосних, К клас твердих задньоязикових, Т - клас твердих передньоязикових; С̆ - клас шиплячих африкат.

\section{Література}

1. Булыгина Т. В. Проблема теории и практики морфонологического описания / Т. В. Булыгина // Известия АН СССР. Серия литературы и языка. - 1975. - № 4. - С. 328-340.

2. Винокур Г. О. Заметки по русскому словообразованию // Винокур Г. О. Избранные работы по русскому языку. - М. : Учпедгиз, 1959. - С. 419-442.

3. Горпинич В. О. Сучасна українська літературна мова. Морфеміка. Словотвір. Морфонологія / В. О. Горпинич. - К. : Вища шк., 1999. - 207 с.

4. Демешко I. М. Функціональні морфонологічні класи приголосних при творенні віддієслівних дериватів в українській мові // Культура народов Причерноморья [редкол. Катунин Ю. А. и др.] / І. М. Демешко. - Симферополь: ИИО КРИППО, 2007. - № 110. - Т. 1. - С. 154-156.

5. Демешко I. М. Морфонологические позиции и условия альтернаций в словообразовательных парадигмах отглагольных существительных в современном украинском языке // Актуальные вопросы современного словообразования [под общ. ред. проф. Л. А. Араевой]. - Вып. 2. / І. М. Демешко. Кемерово: Кузбассвузиздат, 2008. - С. 91-96.

6. Лопатин В. В. Русская словообразовательная морфемика / В. В. Лопатин. - М. : Наука, 1977. - 315 с.

7. Мейе А. Введение в сравнительное изучение индоевропейских языков: [пер. Д. Кудрявского, перераб. и доп. по 7-ому фр. изд. А. Сухотиным]. - [под ред. и с прим. Р. Шор. Вступ. ст. М. Сергиевского]. / А. Мейе. - М. - Л. : Гос. соц.-эконом. изд-во, 1938. - С. 5-26.

8. Тихонов А. Н. Словообразовательный словарь русского языка : В 2 т. - [2-е изд., стер.]. - Т. 2 / А. Н. Тихонов. - М. : Рус. яз., 1990. - 886 с.

9. Толстая С. М. Морфонология в структуре славянских языков / С. М. Толстая. - М. : Индрик, 1998. -318 c. 